\title{
Hubungan Tingkat Pengetahuan Kesehatan Reproduksi pada Remaja Perempuan dengan Sikap Seksual Pranikah
}

\author{
Yuni Kurniati \\ Akademi Kebidanan Budi Mulia Palembang
}

Informasi Artikel :

Diterima : 24 November 2021

Direvisi : 03 Desember 2021

Disetujui : 20 Desember 2021

Diterbitkan : 30 Desember 2021

*Korespondensi Penulis : yunikurniati80@gmail.com

\section{A B S T R A K}

Badan Kependudukan dan Keluarga Berencana (BKKBN), rentang usia remaja adalah 10-24 tahun dan belum menikah.Kesehatan reproduksi adalah keadaan sehat secara fisik, mental dan sosial secara utuh, tidak semata-mata bebas dari penyakit atau kecacatan yang berkaitan dengan sistem, fungsi dan proses reproduksi. Pentingnya pengetahuan kesehatan reproduksi bagi remaja karena pada masa remaja merupakan waktu terbaik untuk membangun kebiasaan baik terutama dalam menjaga kebersihan yang menjadi aset sangat penting dalam jangka panjang khususnya remaja puteri. Jenis penelitian ini observasional dengan metode penelitian survei analitik. Penelitian ini menggunakan pendekatan cross sectional. Populasi dalam penelitian ini adalah seluruh mahasiswi budi mulia yang berumur 18-21 tahun sebanyak 79 mahasiswi. Sampel pada penelitian ini berjumlah 55 sampel. Dengan menggunakan teknik purposive sampling. Penelitian ini dilakukan di Akademi Kebidanan Budi Mulia Palembang pada bulan Oktober tahun 2021.Hasil penelitian diperoleh responden dengan kualifikasi pengetahuan kurang dan terkategori memiliki sikap negatif berjumlah 2 responden $(3,6 \%)$. Sedangkan responden dengan kualifikasi pengetahuan kurang dengan sikap positif berjumlah 0 responden $(0 \%)$. Responden dengan pengetahuan kesehatan reproduksi baik dan memiliki sikap negatif berjumlah 4 responden (7,3\%). Diketahui juga responden dengan pengetahuan kesehatan reproduksi pada remaja terkategori baik dan memiliki sikap positif berjumlah 44 responden $(80 \%)$.Kesimpulan penelitian berdasarkan hasil analisis bivariat diperoleh $P$ Value $0,000<\alpha=0,05$ berarti bahwa $\mathrm{H} 1$ diterimayaitu terdapat hubungan bermakna antara tingkat pengetahuan kesehatan reproduksi pada remaja dengan sikap seksual pranikah di Akademi Kebidanan Budi Mulia Palembang Tahun 2021.

\section{Kata Kunci : Sikap Seksual Pranikah, Kesehatan Reproduksi, Remaja Perempuan}

\begin{abstract}
Badan Kependudukan dan Keluarga Berencana(BKKBN), the age range of adolescents is 10-24 years and is not married. Reproductive health is a state of complete physical, mental and social health, not merely free from disease or disability related to reproductive systems, functions and processes. The importance of reproductive health knowledge for adolescents because adolescence is the best time to build good habits, especially in maintaining cleanliness which is a very important asset in the long term, especially young women. This type of research is observational with an analytical survey research method. This study used a cross sectional approach. The population in this study
\end{abstract}


were all noble students aged 18-21 years as many as 79 female students. The sample in this study amounted to 55 samples. By using purposive sampling technique. This research was conducted at the Budi Mulia Midwifery Academy in Palembang in October 2021. The results obtained that respondents with less knowledge qualifications and categorized as having a negative attitude amounted to 2 respondents (3.6\%). While respondents with less knowledge qualifications with a positive attitude amounted to 0 respondents (0\%). Respondents with good reproductive health knowledge and negative attitudes were 4 respondents (7.3\%). It is also known that respondents with knowledge of reproductive health in adolescents are categorized as good and have a positive attitude totaling 44 respondents (80\%). The conclusion of the study based on the results of bivariate analysis obtained $P$ Value $0.000=0.05$ meaning that $\mathrm{HI}$ is accepted, namely there is a significant relationship between the level of knowledge of reproductive health in adolescents with premarital sexual attitudes at the Budi Mulia Midwifery Academy Palembang in 2021.

\section{Keywords : Premarital Sexual Attitude, Reproductive Health, Adolescent Girls}

\section{PENDAHULUAN}

Remaja adalah seseorang yang berada dalam masa peralihan dari anak-anak menuju dewasa. Menurut WHO, masa remaja terjadi dalam rentang usia 10-19 tahun. Sementara, menurut peraturan Menteri Kesehatan RI Nomor 25 tahun 2014 arti remaja merupakan penduduk yang berusia 10-18 tahun. Sedangkan, Badan Kependudukan dan Keluarga Berencana (BKKBN), rentang usia remaja adalah 10-24 tahun dan belum menikah. Jumlah kelompok usia 10-19 tahun di Indonesia menurut Sensus Penduduk 2010 sebanyak 43,5 juta atau sekitar $18 \%$ dari jumlah penduduk. Di dunia diperkirakan kelompok remaja berjumlah 1,2 milyar atau $18 \%$ dari jumlah penduduk dunia (WHO, 2014).

Masa remaja merupakan periode terjadinya pertumbuhan dan perkembangan yang pesat baik secara fisik, psikologis, maupun intelektual. Sifat khas remaja memiliki rasa keingintahuan yang besar, menyukai petualangan dan tantangan serta cenderung berani menanggung resiko atas perbuatannya tanpa didahului oleh pertimbangan yang matang. Apabila ternyata keputusan yang diambil dalam menghadapi konflik tidak tepat, mereka akan jatuh ke

dalam perilaku beresiko dan mungkin akan menanggung akibat jangka pendek dan jangka panjang dalam berbagai masalah kesehatan fisik dan psikososial. Sifat dan perilaku beresiko pada remaja tersebut memerlukan ketersediaan pelayanan kesehatan peduli remaja yang dapat memenuhi kebutuhan kesehatan remaja termasuk pelayanan untuk kesehatan reproduksi.

Kesehatan reproduksi adalah keadaan sehat secara fisik, mental dan sosial secara utuh, tidak semata-mata bebas dari penyakit atau kecacatan yang berkaitan dengan sistem, fungsi dan proses reproduksi. Data mengenai situasi kesehatan reproduksi remaja sebagian besar bersumber dari Survei Demografi dan Kesehatan terutama komponen Kesehatan Reproduksi Remaja (KRR), yang mewawancarai remaja usia 15-24 tahun dan belum menikah. Pada remaja usia 15-19 tahun, proporsi terbesar berpacaran pertama kali pada usia 15-17 tahun. Sekitar 33,3\% remaja perempuan dan $34,5 \%$ remaja laki-laki yang berusia 15-19 tahun mulai berpacaran pada saat mereka belum berusia 15 tahun. Pada 
usia tersebut dikhawatirkan belum memiliki keterampilan hidup (life skill) yang memadai, sehingga mereka beresiko memiliki perilaku pacaran yang tidak sehat, antara lain melakukan hubungan seks pra nikah (Kemenkes RI, 2016).

Pentingnya pengetahuan kesehatan reproduksi bagi remaja karena pada masa remaja merupakan waktu terbaik untuk membangun kebiasaan baik terutama dalam menjaga kebersihan yang menjadi aset sangat penting dalam jangka panjang khususnya remaja puteri. Orang tua memiliki peran yang sangat penting dalam kehidupan remaja, sehingga orang tua perlu lebih intensif dalam menanamkan nilai moral yang baik kepada remaja. Diantaranya, dengan menjelaskan kerugian yang ditimbulkan dari hubungan seksual pranikah dari segala sisi dan penyakit yang dapat ditularkan dari perilaku seks yang beresiko hingga konsekuensi dari ketidaksiapan mental dan finansial dalam memulai kehidupan berumah tangga akibat kehamilan yang tidak terencana.

Menurut United Nations Development Economic and Social Affairs (UNDESA, 2010), Indonesia termasuk negara ke-37 dengan persentase pernikahan usia muda yang tinggi dan merupakan yang tertinggi kedua di ASEAN setelah Kamboja. Pada tahun 2010, terdapat 158 negara dengan usia legal minimal perempuan menikah ialah 18 tahun keatas, namun di Indonesia batas usia minimal untuk perempuan adalah 16 tahun. Menurut SDKI tahun 1991-2012 usia menikah pertama wanita usia 25 sampai 49 tahun sudah diatas 16 tahun. Pernikahan usia muda beresiko karena belum cukupnya kesiapan dari aspek kesehatan, mental emosional, pendidikan, sosial ekonomi, dan reproduksi. Pendewasaan usia perkawinan juga berkaitan dengan pengendalian kelahiran karena lamanya masa subur perempuan terkait dengan banyaknya anak yang akan dilahirkan.
Kehamilan remaja berdampak negatif pada kesehatan remaja dan bayinya, juga dapat berdampak sosial dan ekonomi. Kehamilan pada usia muda atau remaja antara lain beresiko kelahiran prematur, berat bayi lahir rendah (BBLR), perdarahan persalinan, yang dapat meningkatkan kematian ibu dan bayi. Kehamilan pada remaja juga terkait dengan kehamilan tidak dikehendaki dan aborsi tidak aman. Persalinan pada ibu dibawah usia 20 tahun memiliki kontribusi dalam tingginya angka kematian neonatal, bayi, dan balita. SDKI 2012 mendapatkan bahwa angka kematian neonatal, postneonatal, bayi dan balita pada ibu yang berusia kurang dari 20 tahun lebih tinggi dibandingkan pada ibu yang berusia kurang dari 20-39 tahun. Angka fertilitas kelompok 15-19 tahun (Age Specific Fertility Rate, ASFR 1519)menunjukkan penurunan yang tidak signifikan dalam 5 tahun terakhir, masih jauh dari target RPJMN 2014 yaitu 30 kelahiran per 1000 perempuan (SDKI 2012, Badan Pusat Statistik).

Berdasarkan riset kesehatan dasar (Riskesdas) 2013, yang mendata perempuan usia 10-54 tahun, yang sedang hamil, masih didapatkan kehamilan pada usia sangat muda ( $<15$ tahun), meskipun dengan proporsi yang sangat kecil $(0,02 \%)$, terutama dipedesaan $(0,03 \%)$. Sedangkan proporsi kehamilan pada usia 15-19 tahun adalah 1,97\% dipedesaan lebih tinggi daripada diperkotaan (SDKI 1991-2012, Badan Pusat Statistik).

Hasil SDKI 2012, berhubungan dengan informasi remaja mengenai kesehatan reproduksi menunjukkan bahwa pengetahuan remaja tentang kesehatan reproduksi belum memadai yangdapat dilihat dengan hanya $35,3 \%$ remaja perempuan dan $31,2 \%$ remaja laki-laki usia 15-19 tahun mengetahui bahwa perempuan dapat hamil dengan satu kali berhubungan seksual. Begitu pula gejala penyakit menular seksual kurang diketahui oleh remaja. Dari data teman diskusi dan 
sumber informasi kesehatan reproduksi yang disukai terlihat bahwa peranan teman sebaya, guru dan tenaga kesehatan, berpotensi untuk meningkatkan pengetahuan mengenai kesehatan reproduksi bagi ramaja. Pada remaja perempuan, peran ibu (40\%) merupakan yang paling tinggi memperoleh informasi mengenai kesehatan reproduksi. Selanjutnya peran petugas kesehatan sebesar $35,7 \%$. Sedangkan remaja laki-laki mendapatkan informasi kesehatan reproduksi diperoleh dari teman sebesar 33,3\%. Selanjutnya remaja laki-laki mendapatkan informasi kesehatan reproduksi dari guru sebesar $29, \%$.

Pada saat ini, tidak dapat dipungkiri bahwa perkembangan informasi sangatlah cepat. Melalui teknologi informasi, remaja sangat mudah mengakses segala pengetahuan. Tanpa harus malu untuk bertanya langsung kepada orang tua, guru, ataupun pemuka agama. Mahasiswi kebidanan telah mendapat informasi berkenaan kesehatan reproduksi. Karena itulah peneliti sangat tertarik untuk mengetahui “ Apakah hubungan tingkat pengetahuan kesehataan reproduksi remaja perempuan dengan sikap seksual pranikah pada mahasiswi di Akademi Kebidanan Budi Mulia Palembang tahun 2021?”.

\section{METODE PENELITIAN}

Jenis penelitian ini observasional dengan metode penelitian survei analitik yaitu survei atau penelitian yang menggali bagaimana dan mengapa fenomena kesehatan itu terjadi (Notoadmojo, 2012). Penelitian ini menggunakan pendekatan cross sectional adalah suatu penelitian untuk mempelajari dinamika korelasi antara faktor-faktor resiko dengan efek, dengan cara pendekatan observasi atau pengumpulan data sekaligus suatu saat. Alat ukur menggunakan kuesioner tertutup dimana jawaban dalam kuesioner sudah ditentukan terlebih dahulu dan respponden tidak diberi kesempatan memberi jawaban lain.Populasi dalam penelitian ini adalah seluruh mahasiswi budi mulia yang berumur 18-21 tahun sebanyak 79 mahasiswi. Sampel pada penelitian ini berjumlah 55 sampel. Dengan menggunakan teknik purposive sampling. Penelitian ini dilakukan di Akademi Kebidanan Budi Mulia Palembang pada bulan Oktober tahun 2021.

\section{HASIL PENELITIAN}

\section{Analisis Univariat}

Dari hasil penyebaran angket yang dilakukan terhadap 55 responden kepada mahasiswi Akademi Kebidanan Budi Mulia Palembang tahun 2021 didapatkan hasil sebagai berikut:

\section{Karakteristik Responden}

\section{Berdasarkan Usia}

Tabel 1.Distribusi Frekuensi Responden Berdasarkan Usia

\begin{tabular}{clll}
\hline No. & Usia Responden & Frekuensi & \% \\
\hline 1 & 18 tahun & 29 & 52,7 \\
2 & 19 tahun & 19 & 34,5 \\
3 & 20 tahun & 6 & 10,9 \\
4 & 21 tahun & 1 & 1,8 \\
\hline & Total & 55 & 100 \\
\hline
\end{tabular}

Berdasarkan data yang diperoleh pada tabel 1 diketahui bahwa jumlah responden yang berumur 18 tahun sebanyak 29 responden $(52,7 \%)$, responden yang berumur 19 tahun berjumlah 19 responden $(34,5 \%)$, responden yang berumur 20 tahun sebanyak 6 responden $(10,9 \%)$, dan responden yang berumur 21 tahun sebanyak 1 responden $(1,8 \%)$. Keseluruhan responden berjenis kelamin perempuan.

\section{Tingkat pengetahuan responden tentang kesehatan reproduksi}

Tabel 2. Distribusi Frekuensi Responden Berdasarkan Tingkat Pengetahuan Kesehatan Reproduksi

\begin{tabular}{llcc}
\hline No. & Kategori & Frekuensi & \% \\
\hline 1 & Kurang & 2 & 3,6
\end{tabular}




\begin{tabular}{ccccc}
\hline \hline 2 & Cukup & 5 & & 9,1 \\
3 & Baik & 48 & & 87,3 \\
\hline & Total & & 55 & 100 \\
\hline
\end{tabular}

Setelah dilakukan penilaian terhadap angket berupa kuesioner tentang kesehatan reproduksi, dapat diketahui bahwa dari 55 responden terdapat 2 responden $(3,6 \%)$ yang tergolong memiliki pengetahuaan kesehataan reproduksi terkategori kurang. Responden terkategori memiliki pengetahuan kesehatan reproduksi yang cukup berjumlah 5 responden (9,1\%). Kategori Baik didapat sebanyak 48 responden $(87,3 \%)$, ini menunjukkan banyak mahasiswi Akademi Kebidanan Budi Mulia Palembang memiliki pengetahuan kesehatan reproduksi yang baik.

\section{Sikap Responden Terhadap Seksual Pranikah}

Tabel 3. Distribusi Frekuensi Responden Berdasarkan Sikap Seksual Pranikah

\begin{tabular}{clcc}
\hline No. & Sikap & Frekuensi & \% \\
\hline 1 & Negatif & 7 & 12,7 \\
2 & Positif & 48 & 87,3 \\
\hline \multicolumn{2}{c}{ Total } & 55 & 100 \\
\hline
\end{tabular}

Berdasarkan data pada tabel 3 diketahui bahwa responden yang memiliki sikap negatif terhadap seksual pranikah sebanyak 7 responden (12,7\%). Sikap responden terhadap seksual pranikah yang terkategori positif berjumlah 48 responden $(87,3 \%)$ dari keseluruhan respoden berjumlah 55 mahasiswi (100\%).

\section{Analisis Bivariat}

\section{Hubungan Tingkat Pengetahuan Kesehatan Reproduksi Remaja dengan Sikap Seksual Pranikah}

Tabel 4. Hubungan Tingkat Pengetahuan Kesehatan Reproduksi pada Remaja dengan Sikap Seksual Pranikah pada Mahasiswi Akademi Kebidanan Budi Mulia Palembang Tahun 2021

\begin{tabular}{ccccccc}
\hline \multirow{2}{*}{$\begin{array}{c}\text { Kategori } \\
\text { Pengetahuan }\end{array}$} & \multicolumn{4}{c}{ Sikap } & \multicolumn{2}{c}{ Total } \\
\cline { 2 - 6 } & Negatif & \multicolumn{3}{c}{ Positif } & \multicolumn{2}{c}{} \\
\cline { 2 - 6 } & Frekuensi & $\%$ & Frekuensi & $\%$ & Frekuensi & $\%$ \\
\hline Kurang & 2 & 3,6 & 0 & 0 & 2 & 3,6 \\
Cukup & 1 & 1,8 & 4 & 7,3 & 5 & 9,1 \\
Baik & 4 & 7,3 & 44 & 80 & 48 & 87,3 \\
\hline Jumlah & 7 & 12,7 & 48 & 87,3 & 55 & 100 \\
\hline
\end{tabular}

Dari tabel 4 diketahui hubungan tingkat pengetahuan kesehatan reproduksi pada remaja dengan sikap seksual pranikah. Responden dengan kualifikasi pengetahuan kurang dan terkategori memiliki sikap negatif berjumlah 2 responden (3,6\%). Sedangkan responden dengan kualifikasi pengetahuan kurang dengan sikap positif berjumlah 0 responden (0\%). Responden dengan pengetahuan kesehatan reproduksi baik dan memiliki sikap negatif berjumlah 4 responden (7,3\%). Diketahui juga responden dengan pengetahuan kesehatan reproduksi pada remaja terkategori baik dan memiliki sikap positif berjumlah 44 responden $(80 \%)$. 
Tabel 5. Hasil Uji Statistik Analisis Bivariat Mengenai Hubungan Tingkat Pengetahuan Kesehatan Reproduksi pada Remaja dengan Sikap Seksual Pranikah pada Mahasiswi Akademi Kebidanan Budi Mulia Palembang Tahun 2021

\begin{tabular}{|c|c|c|c|}
\hline Hipotesis & $\alpha$ & P value & Hasil \\
\hline $\begin{array}{l}\text { H0 = Tidak ada hubungan bermakna antara tingkat } \\
\text { pengetahuan kesehatan reproduksi pada remaja } \\
\text { dengan sikap seksual pranikah di Akademi Kebidanan } \\
\text { Budi Mulia Palembang Tahun } 2021\end{array}$ & \multirow{2}{*}{0,05} & \multirow{2}{*}{0,000} & \multirow{2}{*}{$\begin{array}{l}\text { H1 Diterima dan } \\
\text { H0 Ditolak }\end{array}$} \\
\hline $\begin{array}{l}\text { H1 = Terdapat hubungan bermakna antara tingkat } \\
\text { pengetahuan kesehatan reproduksi pada remaja } \\
\text { dengan sikap seksual pranikah di Akademi Kebidanan } \\
\text { Budi Mulia Palembang Tahun } 2021\end{array}$ & & & \\
\hline
\end{tabular}

\section{PEMBAHASAN}

\section{Analisa Univariat}

Berdasarkan data pada tabel 1 , diketahui bahwa responden terdiri dari 55 orang mahasiswi. Dari 55 mahasiswi ini yang paling banyak diambil sebagai responden untuk menjawab angket berumur 18 tahun dengan jumlah responden sebanyak 29 (52,7\%). Sedangkan yang berusia 19 tahun berjumlah 19 responden (34,5\%), yang berusia 20 tahun berjumlah 6 responden $(10,9 \%)$, dan yang paling sedikit berumur 21 tahun hanya berjumlah 1 responden $(1,8 \%)$. Hal ini terjadi kerena pada tingkat satu mahasiswi pada umumnya masuk pada usia 18 tahun. Yang bearti pada usia 20 tahun rata-rata mahasiswi sudah berada di tingkat III yang merupakan tingkat akhir di program studi D III Kebidanan.

Dari data pada tabel 2, dapat diketahui bahwa distribusi frekuensi responden berdasarkan tingkat pengetahuan kesehatan reproduksi dengan kategori baik, berjumlah 48 responden $(87,3 \%)$. Hal ini menunjukkan bahwa responden yang merupakan mahasiswi Akademi Kebidanan Budi Mulia Palembang hampir seluruhnya memiliki pengetahuan yang baik mengenai kesehatan reproduksi. Terdapat 5 responden $(9,1 \%)$ yang terkategori cukup. Dan hanya 2 responden yang terkategori kurang.

Data dari tabel 3 menunjukkan sikap responden terhadap seksual pranikah yang memiliki sikap positif jauh lebih banyak jumlahnya yaitu 48 responden (87,3\%), sedangkan yang memilki sikap negatif berjumlah 7 responden $(12,7 \%)$.

\section{Analisa Bivariat}

Data dari tabel 4 diketahui bahwa responden dengan pengetahuan kesehatan reproduksi kuran dan memiliki sikap negatif berjumlah 2 responden (3,6\%). Responden dengan pengetahuan yang cukup dan memiliki sikap seksual pranikah negatif hanya berjumlah 1 responden (1,8\%). Responden dengan pengetahuan baik tetapi memilki sikap seksual pranikah negatif berjumlah 4 responden $(7,3 \%)$. Hal ini dapat terjadi karena selain faktor pengetahuan, terdapat hal lain yang dapat mempengaruhi sikap seksual pranikah sesesorang ke arah yang negatif seperti tidak terfilternya tayangan di medsos dan pergaulan. Sedangkan responden dengan pengetahuan yang kurang dan memiliki sikap yang positif, tidak ada $(0 \%)$. Hal ini menunjukkan bahwa pengetahuan terhadap kesehatan reproduksi berperan dalam menentukan sikap responden terhadap sikap sesksual pranikah. Responden dengan pengetahuan kesehatan reproduksi yang cukup dan memilki sikap positif berjumlah 4 responden (7,3\%). Jumlah ini lebih banyak dibandingkan dengan responden yang memiliki pengetahuan cukup tetapi memiliki sikap negatif yang berjumlah 1 responden. Hal ini menunjukkan dengan pengetahuan yang cukup akan memberi dampak untuk seseorang memiliki sikap positif lebih banyak, dibandingkan sikap negatif. Responden dengan kategori memiliki pengetahuan baik tetapi memiliki sikap negatif berjumlah 4 responden $(7,3 \%)$. Jumlah ini jauh lebih kecil dibandingkan dengan responden kategori pengetahuan kesehatan reproduksi baik dan memiliki sikap positif berjumlah 80 responden $(87,3 \%)$. Hal ini dapat terjadi karena selain usia responden 18 sampai dengan 21 tahun 
membuatnya semakin matang dalam pengetahuan kesehatan reproduksi yang baik dan menentukan sikap seksual pranikah yang positif. Berdasarkan hasil analisis bivariat diperoleh $P$ Value $0,000<\alpha$ $=0,05$ berarti bahwa $\mathrm{H} 1$ diterimayaitu terdapat hubungan bermakna antara tingkat pengetahuan kesehatan reproduksi pada remaja dengan sikap seksual pranikah di Akademi Kebidanan Budi Mulia Palembang Tahun 2021. Hasil ini sama dengan penelitian Husna tahun 2017 yang menyatakan terdapat hubungan antara pengetahuan dan sikap remaja tentaang seks pranikah di SMKN 2 Sewon Bantul. Pada penelitian Husna tahun 2017 diperoleh data sebagian besar remaja berpengetahuan cukup $57,7 \%$ tentang seks pranikah dan mempunyai sikap yang tidak mendukung/negatif sebanyak $67,2 \%$ tentang seks pranikah. Penelitian ini juga sejalan dengan Raudhati (2014) yang menyatakan ada hubungan yang bermakna antara pengetahuan kesehatan reproduksi dengan sikap remaja tentang seksual pranikah.

Golongan remaja akhir berusia 18-22 tahun, memiliki karakter yaitu minat yang semakin mantap terhadap fungsi-fungsi intelek, egonya mencari kesempatan untuk bersatu dengan orang lain dan dalam mencari pengalaman baru, terbentuk identitas seksual yang tidak akan berubah lagi, terdapat keseimbangan antara kepentingan diri sendiri dengan orang lain. Banyak tuntutan dari beberapa faktor religius, sosial dan juga nilai serta norma yang bisa mendorong remaja untuk bisa mulai memikul beban dan tanggung jawab. Harapan dan juga tuntutan tersebut yang nantinya melatarbelakangi beberapa tugas baru dalam perkembangan remaja termasuk juga remaja akhir.

Angka aktifitas seksual pada anak di bawah umur di Kabupaten Semarang cukup tinggi. Data tahun 2016 disebutkan 347 anak di bawah umur melaksanakan pernikahan yang diakibatkan seks pranikah. Pengawasan anak tak hanya menjadi tanggung jawab sekolah atau guru, namun juga menjadi tanggung jawab pihak keluarga dan masyarakat (Amanda, 2017). Pelibatan remaja dalam kependudukan dan keluarga berencana merupakan implementasi kesepakatan konferensi internasional kependudukan dan pembangunan (ICPD) sebagai upaya pemenuhan hak-hak kesehatan reproduksi dan seksual. Sesuai tugas pokok BKKBN dalam menyelenggarakan pengendalian penduduk dan keluarga berencana, remaja merupakan sasaran program KKBPK. Dalam upaaya menurunkan kelahiran total (TFR) melalui penurunan kelahiran di kelompok remaja (ASFR 15-19 tahun) dengan upaya pendewasaan usia perkawinan (meningkatkan usia pertama kawin perempuan) (BKKBN, 2018).

\section{KESIMPULAN}

Terdapat hubungan bermakna antara tingkat pengetahuan kesehatan reproduksi pada remaja dengan sikap seksual pranikah di Akademi Kebidanan Budi Mulia Palembang Tahun 2021.

\section{DAFTAR PUSTAKA}

Amanda. 2017. Ada 347 Pernikahan Anak di Bawah umur di Kabupaten Semarang Karena Seks Pranikah.

http://jateng.tribunnews.com/2018/01/24/ad a-347-pernikahan-anak-di-bawah-umur-dikabupaten-semarang-karena-seks-pranikah.

Badan Kependudukan Keluarga Berencana Nasional. (2013). Kurikulum Diklat Teknis Pengelolaan PIK Remaja/Mahasiswa Bagi Pengelola, Pendidik Sebaya dan Konselor Sebaya PIK Remaja/Mahasiswa. Jakarta.

BBKBN.2018. Pendidikan Kesehatan Reproduksi Bagi Generasi Muda.

https://www.bkkbn.go.id/pocontent/uploads/2018.03.09.Banjarmasin.Pe ndidikan_Kespro_Generasi_Muda.pdf diakses 18 Oktober 2021

Bernaded Mares.

https://dosenpsikologi.com/konseppsikologi-perkembangan-remaja-akhir diakses 23 Oktober 2021

BKKBN, 2019.

https://www.bkkbn.go.id/detailpost/kalauterencana-semua-lebih-indah diakses 18 Oktober 2021

Dewi, A. C., Tinggi, S., Kesehatan, I., \& Surakarta, A. (2012). Hubungan antara tingkat pengetahuan ibu kesehatan reproduksi remaja, 9(2), 17-25. Retrieved from http://jurnal.stikes- 
aisyiyah.ac.id/index.php/gaster/article/view/ $\underline{36 / 33}$

Husna, F dan Ariningtyas, N. 2017. Hubungan Tingkat Pengetahuan dan Sikap Remaja Puteri Tentang Seks Pra Nikah. Akademi Kebidanan Nyai Ahmad Dahlan Yogyakarta

Kartono, Kartini. 2011. Patologi Sosial. Jakarta : Rajawali Pres.

Muflih. 2014. Pengetahuan Kesehatan Reproduksi Berhubungan Dengan Kepercayaan Diri Remaja Untuk Menghindari Seks Bebas. Jurnal Keperawatan, 5(1), 23-30.

Retrieved from http://ejournal.umm.ac.id/index.php/kepera watan/article/view/1857

Partini. 2013. Komunikasi Sosial (melalui smartphone) sebagai sumber informasi seksual:Ancaman Bagi Kesehatan Reproduksi Remaja. Universitas Gajah Mada. Jurnal PKS 11 (1): 1-11

Pusat Data dan Informasi Kementrian Kesehatan RI. 2016. https://pusdatin.kemkes.go.id/resources/do wnload/pusdatin/infodatin/infodatinreproduksi-remaja.pdf diakses 20 Oktober $\underline{2021}$

Raudhati, S dan Novianti, R. 2014. Pengetahuan Kesehatan Reproduksi dengan Sikap Remaja Tentang Seksual Pranikah.Lentera, 11(10):1-4

Soekidjo, Notoatmojo. 2016. Promosi Kesehatan dan Ilmu Perilaku. Jakarta : Rineka Cipta

Soekodjo, Notoatmojo. 2012. Metodologi Penelitian Kesehatan. Jakarta: Rineka Cipta

Soetjiningsih. 2010. Tumbuh Kembang Remaja dan Permasalahanya. Jakarta.

Verury Verona Handayani. 2021. https://www.halodoc.com/artikel/caraedukasi-kesehatan-reproduksi-pada-anakremaja diakses 20 Oktober 2021
Wahhab. 2020.

https://dppkbpmd.bantulkab.go.id/kesehata n-reproduksi-remaja/ diakses 28 september 2021 